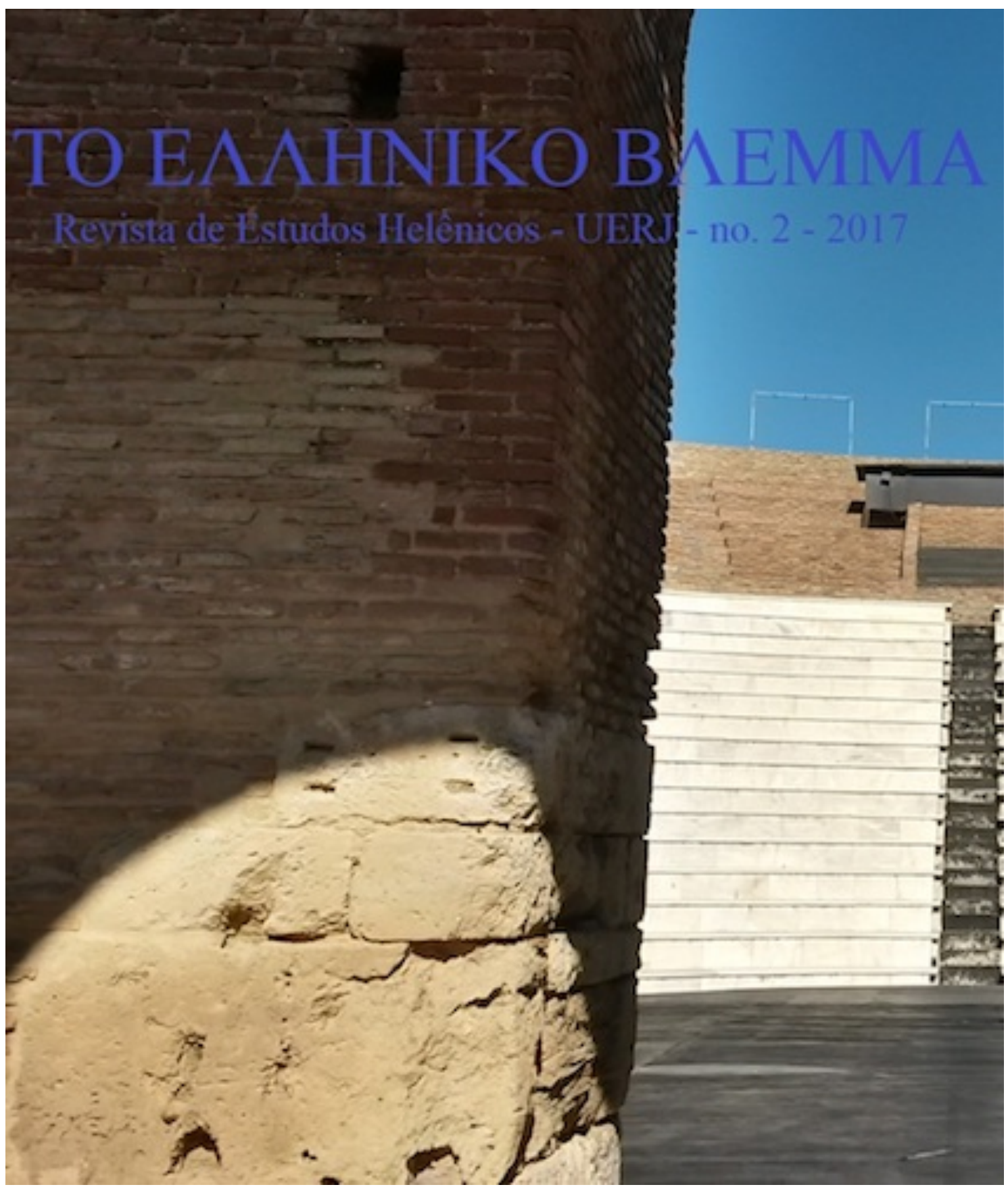




\title{
The Scents of the Child, Memory and Children's Books: Alternative perspectives in culture and teaching methodology
}

\author{
Smaragda Papadopoulou \\ Department of Primary Education \\ University of Ioannina, Greece \\ smpapado@cc.uoi.gr
}

\begin{abstract}
This study reflects on theories and practices of scented/smelly books as a fact which could give new perspectives in writing for children and creating children's books. This impact can be an alternative methodological tool for children's learning at school. Smell has very high retention rate in the learning process that influences the memory of a story and the impact to children's imagination and experience in the world around. This forgotten value at school textbooks can be re-examined from specialists. Scented books as a teaching strategy and a methodological tool reveal how children can represent memories and express themselves effectively in a language class with the help of using smelly books. In our study, we expected children to remember the main or essential points as a bottom-line of story plots when scents were involved between the child and the book. Perfume literacy in children's book and the e-book industry refer as theoretical components in our study and are described in detail. It is true that civilization has cost people a valuable sense. A nose alphabet could also arrange things in different perspectives for young children.
\end{abstract}

Key words: Scented children's Books, Teaching, Language

\section{Resumo}

Este estudo reflete sobre teorias e práticas de livros perfumados/aromatizados como um fato que poderia dar novas perspectivas na escrita para crianças e na criação de livros infantis. Esse impacto pode ser uma ferramenta metodológica alternativa para o aprendizado infantil na escola. $\mathrm{O}$ aroma tem uma taxa de retenção muito alta no processo de aprendizagem que influencia a memória de uma história, o impacto na imaginação e a experiência das crianças no mundo todo. Este valor esquecido nos livros escolares pode ser reexaminado por especialistas. Livros perfumados como uma estratégia de ensino e uma ferramenta metodológica revelam como as crianças podem representar memórias e se expressar, efetivamente, em uma aula de linguas com a ajuda do uso de livros aromatizados. Em nosso estudo, esperávamos que as crianças se lembrassem dos pontos principais ou essenciais, como linhas mestras de enredos de histórias quando os aromas estivessem envolvidos entre a criança e o livro. A literalidade do perfume no livro infantil e a indústria do e-book se referem como componentes teóricos em nosso estudo e são descritas em detalhes. É verdade que a civilização custou às pessoas um sentido valioso. Um alfabeto do nariz também pode organizar as coisas em diferentes perspectivas para crianças pequenas.

Palavras-chave: Livros infantis perfumados, Ensino, Linguagem 
"Smell [..] is a highly elusive phenomenon. Odours, unlike colors, for instance, cannot be named - at least not in European languages. 'It smells like...', we have to say when describing an odour, groping to express our smell experience by means of metaphors. Nor can odours be recorded: there is no effective way of either capturing scents or storing them over time. In the realm of olfaction, we must make do with descriptions and recollections." (C.Classen, D. Howes\&A. Synnott, Aroma: The cultural history of smell, UK: Routledge, 1994, p.3)

\section{Introduction}

Compared with other functions people rely very little on smell. We rather limit ourselves to perceive the world with the help of vision and hearing, while we attribute to sniff a secondary role, for example, do not use to find our way, nor to identify the unmatched us. However, babies recognize their mother by smell and adults are aware subconsciously from the forgotten scent that suddenly enters their nostrils can cause invoking memories and intense emotions.

Scientists have tried to decipher the alphabet of odors. The discovery of odorant receptors spurred many new investigations into the mammalian sense of smell. When educators try to put this knowledge in everyday life of school children, a lot of experimentation can occur, (Ferrero et al, 2011).

Light the secrets of smell recently dropped U.S. researchers at the Medical Institute Howard Hughe Harvard University in collaboration with Japanese colleagues of Life Electronics Research Center in Amagasaki. Investigating how the nose - which has a relatively small number of odorant receptors, (proteins, which are found in certain cells of the epithelium of the nasal cavity and which "capture" molecules arriving there) $\neg$ able to recognize and distinguish thousands of different odors, professor Linda Buck and colleagues decoded the mechanism of smell. According to an article by researchers in the journal "Cell", the sense of smell in mammals is based on a combinatorial approach to the identification and registration of odors. Instead, i.e., corresponding to an olfactory receptor in each odor, olfactory system utilizes an " alphabet" of receptors in order to create the identity of smell perceives the brain( Buck \& Axel, 1991).

As explained Mrs. Buck, "any container used again and again in order to fix an odor, just like the letters used most often to form different words. As to the language, the system utilizes our olfactory receptor combinations (combinations correspond to words) so as to reduce the number of receptors (letters), that are needed to yield a wide range of odors (vocabulary)".

Creating codes resulting from the combination of simpler units is not unknown in nature. Of the four 'letters' of the genetic code (A - adenine, $\mathrm{T}$ thymine , G - guanine and C - cytosine) is formed to an endless number of sequences of genes. However, this is the first time demonstrated how the nerve cells that make up the mammalian olfactory system using same approach. The input from the millions of sensory cells in the nose creates an electrical pattern in the olfactory bulbs, which act like a switching station. From there, the messages containing coded smell information are relayed to various parts of the 
brain. Many of the nerve pathways lead to the temporal lobe, which stores memories, while others connect with the most ancient parts of the brain that deal in the traffic of emotions, sex, appetite and survival behavior. We sense the smell of fear and other emotions. The researchers are discussing this option to identify genetic signatures in the neurons involved in fear responses. If they find unique molecular signatures for these specific neurons and if those signatures occur in humans too, such discoveries could lead to a better understanding of stress disorders, such as PTSD and depression, Buck noticed and perhaps even point to novel targets for therapeutics (2016). In future, this can change all we know about the children's literacy and human knowledge and the interpretations of children's books. There is already evidence suggesting that other scents, like rose oil, can block the fear response to predator odors. Buck's research team is currently working to uncover the neurons that could suppress stress hormones and the fear response in rodents (Kunio Kondoh, Zhonghua Lu, Xiaolan Ye, David P. Olson, Bradford B. Lowell and Linda B. Buck in Nature. Published online March 212016 doi:10.1038/nature17156).

Ethnographic data of how children learn illustrate that smell terms have detailed semantics tapping into broader cultural constructs. Contrary to the widespread view that languages cannot encode odors, the Maniq data show odor can be a coherent semantic domain, thus shedding new light on the limits of language (Wnuka \& Majida, 2014). The recognition of the existence of the alphabet enabled U.S. researchers to provide answers to practical questions. Scientists observed that molecules with similar chemical formula activate different combinations of cells in the olfactory epithelium. This explains why the octanol smells like orange, while octanoic acid smells as sweet. Correspondingly, there is also observed that increased concentrations of the same substance trigger greater variety of cells of the olfactory epithelium. As features Ms. Buck, the novelist on odour science said, " It is a matter of the alphabet." This notion inspired us to try a kind of odour alphabet for children that learn to read.

\section{Creating the $A B C$ of our nose as readers}

From the ancient time and the Greek philosopher Plato till some decades ago there has been the common belief that the experience of a smell is impossible to put into words. But the studies confirmed by observation of scientists have focused on participants from urbanized Western societies. Cross-cultural research suggests that there may be other cultures where odors play a larger role in learning as an education (Burenhult \&Majid 2013, Fendt at al., 2016, Classen at al, 1994 ).

In recent years Professor Linda Buck and colleagues posing a series of logical questions unraveled the tangle of smell, culminating in the discovery of the alphabet. According to an American researcher, their main goal was to investigate the mechanisms and strategies used by our olfactory system to stand the smells. Thanks to their efforts we can now follow the path of odor from the nose as the nerve centers of the brain: as scents entering the nose meets the olfactory epithelium, a cell line that lining the nasal cavity. It is estimated that about five million olfactory nerve cells are located in the olfactory epithelium. On the surface of each of these nerve cells is only one out of 1,000 different types of olfactory receptors. The hiring of odor receptors has therefore activation of nerve cells and their bearing signal transfer to other nerve cells in the olfactory bulb (Buck 1991, 2016, Doty \& Laing, 2003).

It is a brain structure that is the focal point for the perception of odors. From there the signal travels so nervous to the cortex, which manages conscious 
processes and to the centers of the brain, which are associated with the creation of emotions. This explains why an odor besides an actual information, being able to wake up and emotions. For example: the smell of hot milk probably takes adults back in their childhood, (LeDoux,2012 Datta at al., 2011). It is worth noting that the structure of the nerve cells in the different levels of the olfactory system is different. Thus, the olfactory epithelium of the nose there are four different areas, each of which are randomly olfactory nerve cells characteristically olfactory receptors. In other words, an olfactory receptor found only $25 \%$ of the nasal epithelium, but in this zone the location is random. But then information of all the olfactory nerve cells with identical receptors concentrated in the same places in the olfactory bulb, (Brookes at al 2007).

According to Buck, the dispersion of receptors in the epithelium, preserving the sense of smell in cases where a portion of the damaged (for example, after an infection), while at the same time, the convergence of messages from thousands of olfactory cells with the same receptors in certain parts of the brain increases our sensitivity to low concentrations of odors and allows detecting odors even when they are in the environment at low concentrations. Through her research which was for many years, Buck was able to determine how the brain processed different types of smells. She made a portrait of how the brain's olfactory bulb functioned. In 2004, Buck and Axel were named co-recipients of the Nobel Prize in Physiology or Medicine "for their scientific achievements as odorant receptors and the organization of the olfactory system. In 2008 Avery Gilbert gives us a more detailed guide of information about "What the Nose Knows: The Science of Scent in Everyday Life" (Gilbert, 2008).

\section{The Study}

In Greek folk wisdom, the smell is associated with higher mental functions such as perceptual ability and understanding. The allegorical Greek

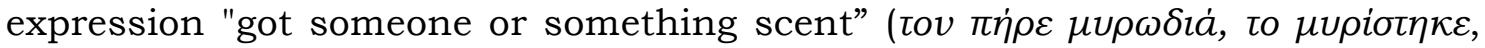
ton pire mirodia, to miristike) characteristically confirms this view. The smell "captured" by the nose is the sense organ of smell, the sense which protects the body from harmful odors, such as poisonous gases (Kratskin \& Belluzzi, 2003). In Creta island in the Mediterranean area there is a weird, kind of uncommon for the rest of Greece formulaic phrase to express the verb "I smell" in the words: "I hear smells". This can involve a more detailed aspect of the way other senses such as hearing serve olfaction.

The operation, though considered simple, is based on the specialized structure to capture and transmit rapidly olfactory stimuli. Specifically, upon inhalation into the nasal cavity entering aromatic molecules of various odors are dissipated in the air. Aromatic molecules stimulate the hairy body area, which stimulates pulsed olfactory neurons. These transmit successive stimuli in the olfactory bulb from which the olfactory nerves travel to different brain centers where their identification is to determine the reactions of the organism to these (Firestein 2001).

Human memory has the ability to record a large body odor which keeps for a very long time arranging them in pleasant or unpleasant - harmful and linking them by association with incidents of everyday life, people or environments. This can make reading literature and involving scents a very personal issue. The ability to smell is a normal function (Kaiser, 2006).

Scents are a cultural component of understanding the world around us: Historical references, (Keller \& Vosshall 2004, Burr 2003) emphasize the use of perfumes in antiquity for perfuming a place of worship or halls. References e.g. 
divination in the stifling atmosphere of incense or the Function Rooms, mysteries or symposia in which herbs from different parts of the then known world flooded the atmosphere, are the texts of many writers of antiquity. As we already noted the olfactory stimuli leaves strong and lasting impressions mnemonic. In fact, it seems that exploited and ecclesiastical environment where incense is one of the ' raw materials cults ' implies how often a student may like going to the church. How can the scents of the church influence the memorization of the story plot and how much the reader liked the story? It may depend on the feelings of the reader for the implied smell in the story and the relationship of the reader with this smell in real life, (Ferrero at al 2011).

Something similar happens in all places of worship, Christian or in mosques, and temples of all religions, especially the ancient eastern where all the senses are stimulated simultaneously, immediately after the entrance to such spaces. Statues, paintings, beauteous architectural or elaborate utensils attract eyesight creating admiration. Melodic sounds delight hearing and scent of incense and offerings of flowers with intense fragrance permeate stimulating atmosphere pleasant smell. At the same time, the gloss by the sense of touch of the barefoot shoe creates feelings of hospitality, security and warmth. Finally, the sense of taste pleasantly excited as believers partake participating in an ecstatic ritual thanksgiving character (Menashe at al., 2003).

The cultural component of ecclesiastical model freshening indoor worshipful living, bringing together for a reasonable period of several dozen believers seem to adopt today and the modern way of organizing the workplace, space habitation, commercial stores and children's books. The trend freshening area tends to spread in open shops, services etc. The long coexistence of workers in the same place inevitably creates odors. Such an atmosphere does not contribute positively to the development of a healthy communicative framework.

A "smelly" workplace e.g. discourages cooperation among employees. Something similar would happen to a home environment where guests will be looking despite the time to leave. Similarly, a commercial - economic environment, such as a shop selling goods or a bank branch, may repel customers, possibly because they would associate with negative connotations and their unpleasant experiences, (Schilling at al., 2010).

Especially for seasoning, the premises has developed huge chemical industry with various aromatic deodorant formulations for every taste, because it has been observed that each man expresses different preference to a particular type of deodorant perfume, which of course chooses. The same applies to the choice of fragrance deal with body odors, as we saw above.

Consensus is the fact that the scent associated with something healthy, pleasant, healthy, safe and harmless to health and generally positive emotions as opposed to the stench that usually emerges from deterioration and rotting. So, by association, the smell associated with life and with the stench of death. This allusion explains why modern flavoring industry and its products worldwide are welcome and extended pouring more and more consumer goods. The sensor captures the smell pleasant odors which connects joyfully past or accept as unprecedented. Somehow, seductive scents work well; not only attracts attention to their emission sources but also affect the purchasing consumer. Commercially e.g. areas of shops flavored, while the goods themselves emit a smell. The smell of new clothes and the shoe is typical. The smells in the detergent section of stores from cleaners or deodorants for any space or object is marked as diffuse tens of perfumes at the same time, which are chemical imitation fruit, flowers or herbs for every taste. In place of the daily diet, diffuse intense natural or artificial odors as amplification products of taste, which is associated with olfaction. Bakery and pastries, coffee, tobacco, 
gasoline, books, newspapers, each emits a unique natural aroma, a united smell, which is certainly stronger in the sales area of each product .Could we predict a book's success in sales from its odor? This could be one of the reasons that readers like reading a storybook, especially in children's industry, (Keller at al, 2007).

Each room has its own distinctive odor depending on the items or products it contains. It is possible in our opinion that school class could affect children's willingness to read stories or does the school work at this function. Every man or every house smells differently. But how "different" is the atmosphere among butchers, fishermen, pharmacies, hospitals , schools , cafes , libraries , clubs , casinos, electrical goods stores or automotive, hairdressing, hotels, police stations, barracks , canteens , restaurants, transportation. There differentiate odors in any room or whether this occurs because of different olfactory capacity of each? Scientifically we put a number of questions that modern science of neuropsychology studies lodges more enlightening answers and education can take advantage of them or estimate this evidence in teaching methods of an unseen emotional and memorizing alphabet - language of odors.

In the education sector, have already penetrated the flavoring industry products aimed, of course, selling and profit. Erasers with varied and pleasant aromas, markers with fruit flavors with aromas of flowers, stationery etc. are some stationery items that attract the attention of children who 'convince their parents to buy them regardless of their usefulness or appropriateness. In the field of electrical engineering trade - attempt if not already achieved construction televisions and computers which, apart from the image and sound will emit odors whereas in this way the viewer or the operator may be experiencing the multisensory ' virtual reality '. In the automotive industry has already tapped the ' aromatic power ' in order to attract buying interest of customers for this type of car whose cabin flavored appropriate to engage the buyer's preference.This use of ' aromatic power ' also utilized in the most profitable way to programs aromatherapy (aromatherapy), which " sell " fragrances for mental well-being to physical relaxation and relief from daily stress, (Roberts\&Williams 1992).

We mostly followed the examples of the older scientists who had twentytwo subjects asked to visualize positive and negative phrases following exposure to either chamomile oil or placebo. Chamomile oil significantly increased the latency for all images, and shifted mood ratings and frequency judgments in a more positive direction, suggesting a possible mode of action for such oils. Also, in other cases in reading and memorizing the plot - experiments with children; subjects were exploited and fragrances were used for this purpose, (Roberts \& Williams 1992, Smith, 1992). We also tried to use stories that children could be interested in and also to present them in a play-training project in reading classrooms.

\section{Our Hypothesis}

1. Normally, olfaction can help children in memorization and understanding of a story.

2.Scents can help express a detailed narration in context.

3. Fairy tales may have scents in descriptions and function characteristically in Greek Literature. 


\section{Our Method}

Ideas for engaging students' sense of smell as they explore the world include the Safe Smelling Method of wafting (waving) an odor towards a nose with the hand instead of sniffing directly from a container. This sensory method was used in order to detect nice odors for children that participated in our study. These scents were included in reading material through storytelling-and listening and reading fairy tales in two ways: Scents as a physical presence in the room/classroom and scents in the symbolic language of the book, (story heard or read).

We encouraged children to tell a story without the stimulation of scents and then with it. So, as we find differences or changes in their speech (oral or written).

Another research of how smells function in typical fairy/folk tales from the Greek geographical region gave us enough teaching material for the case.

\section{Duration of the Study}

Three months, (From September to December 2014) and three months for testing the memory in relation with the story for a longer period of time, (January to February 2015).

\section{Place}

Typical classroom where we used aromatherapy device in accordance with scents that children like (chocolate, vanilla, strawberry, bergamot, lemon, apple) and are known as helping tools for relaxation, concentration, memory (basil rosemary, geranium, jasmine, rose, neroli, ylang ylang). Before each session we opened the windows for fresh air and created the scents of memory at first level and the odors of the story at second level.

\section{Description of the study}

At first place, there was only one vivid scent that was connected to a story. Children which were between 8-10 years old as an experimental group of 60 persons in comparison with the same number of a group at the same school seemed to recall more information with the presence of scents than without scents (short term memory). After the past of months they remembered a more detailed and rich narration of a story when the scent was present in the room which gives us a connection between verbal ability and the application of stimulating the sense of olfaction.

We also tried to see if this verbal capacity is affected in writing. This is why we asked children to write the story instead of telling us. Writing involved fewer mistakes in syntax and morphology of language and a better vocabulary. The content of the story had episodes in detailed description of pictures and persons and children tended to involve other senses in their writing (What the hero was looking like, what was heard at a moment). Especially, to children with a low assessment the results show that senses can help a better linguistic result in terms of a multisensory education by introducing smelly books to young readers and writers. Plot, persons, places, time and incidents of the story were examined in particular items of the children's language. In many ways, expressions of the children were borrowed from the stories we worked at the first three months of the experiment. 


\section{Examples of children's language at children's discourse analysis}

"The bird had the glance of the grass as it smells early in the morning moist" (Andreas 9).

"The firefly donated to the hot air a scent of freedom. When the prisoners in the cave smell it; they escaped before they put in a tomb their chains of slavery and promised each other to live happily ever after" (Sophia 10).

"Get out of here you stink as a badger (8, Marissa)

-But I am a badger/ Can you tell me how it smells?.." (Orestis 10).

"The sun smells like a lemon" (8, Maria)

"The hawk smelled the fear of the bee and helped her find the treasure in the precious egg- looking flower" (Alexandros, 9).

\section{Discussion-Conclusions}

1.From the above remarks and our experimentation with scents in class it follows conclusively that olfaction is a sensation that probably contributes to the realization of non-verbal communication. It relates both protecting the individual from biological threats and secondly by developing psychological and emotional bonds to what can be reflected to language communication whenever scented literature is involved. It therefore appears that the smell can be availed in various communication environments and diverse circumstances. As mentioned in section to flavor space, materials and body, already the production and use of chemical olfactory stimuli has to get well in everyday life consumer consciously contributing under the merchandising, the marketing and promoting over-consumption and therefore profit.

2.The smell is involved in trade marketing, is a fundamental component of interpersonal relations, signing agreements, politics and diplomacy, the fun, the desire of residence or stay in a certain room etcetera. It can be an educational good and an artistic clue between the child and the book at school settings.

The smell is so heuristic in its function that it could be effectively utilized for better adaptation to diverse environments and even in places where many people come together, such as public services, hospitals, asylums, etc. Could be harnessed systematically and in education either as a reinforcing agent in the context of sensory acquisition of knowledge or as a means of recruitment deodorant reasons for addressing odor which creates positive feelings and therefore attracts the children in the area of learning and education, if configured right communication environment.

3.It could finally be used more systematically and in the space of bodily hygiene, aesthetics, educational and cultural areas, in health more widely read in conjunction with the application As we saw above, more and more research in this area highlight the psychosomatic therapeutic and intelligence effect of perfume, especially natural, this can both blow off student's stress and to create a sense of security for children in learning environments. Spearheading the new initiative as a strategic partner is experimental psychologist Professor Charles Spence (2007) who runs the Cross modal Research Laboratory at the University of Oxford. Toby Hoare, CEO of JWT Europe called sensory marketing "something different and increasingly relevant". Professor Spence worked with JWT to evaluate and develop a multitude of sensory marketing implementations, including tactile packaging design, color choice, scent and sound/music. Our 
opinion is that such an experimental use could be a teaching strategy of language and literature approach. Spence has consulted for Unilever, Toyota, Starbucks, VF Group, and Nestlé, on multi-sensory design, branding, and communication. Some of Spence's previous work has focused on designing foods to optimally stimulate the senses and the effect of indoor environment on people's mood, performance and well-being. He has also investigated crossmodal ideas, where sensory input is associated with an entirely different sense. For example, one of his lectures asked "Are lemons fast or slow? Is carbonated water round or angular?" Universally, people tend to answer that lemons are fast and carbonated water is angular, as they associate the taste with other sensations, (speed or shape). The Hello Kitty products, and as a scented book is only an example: An industry of books and other products for children have been produced. We find advertisements that call children to "Just touch the surface of the spine of each chunky board book to release the cherry scent". (http://smellessence.wordpress.com). Scratch and sniff as a hand-made book prepared from teachers is also an example. The scratch and sniff project of reading classrooms could be an experiment for many schools.

\section{The study's sequence in 2016}

In our example, we involved two groups of children of the same age (810) and we asked children to retell a story first, when smells in the room were not involved and after when favorite odors were used for exactly the same procedure with the same children and similar stories in vocabulary, complexity of episodes, number of characters and length of sentences. Stories were of the same difficulty and the only parameter that changed in the procedure was that of the odor involvement. Favorite odors were selected before in a process of interviewing them and children had the chance to try perfumes in order to select the three favorite ones. An otolaryngologist also checked problems of detecting smells with the group of study.

\section{Study's limitations}

Limitation of the study as well as of the experimentation was the possibility of health problems such as allergies to scents or anosmia, (which can be detected at the scent of Moschos/musk at $10 \%$ of population that shares the problem), a phenomenon related to human capacity to interact with scents, children having health problems temporarily with making sense of smells; (such as a common cold, a flu). Anosmia can be caused by either strong or head injury or even from virus infection (Crawford \& Sounder, 1995. Gillyatt, 1997). Gender is also a factor that creates differences in olfactory ability of people. Girls are as our research has shown but and others, too more sensitive to odors and therefore exhibit greater olfactory ability which can perceive even the impending danger from natural disasters (Ackerl et al., 2002)

The use of smells in our study turned to be an alternative advantage with children that have a physical skill in recognizing scents or they are socially aware of scents in the environment from the very first years (This can be proved from parents' interviewing of family habits in cooking, cosmetics and the importance of scents in their discussion)

\section{More Results}

Children's scent awareness can prove to be an advantage for the case of using odors in reading books at school but not with children with a problem in 
the function of smelling temporarily or not temporarily. This means that can be used as an alternative method of learning but not as the only one at the same time. Odors and children's memory was checked a month after the first application of the experiment: It became clear that scents are important for children in order to demonstrate what happened in a story and remember person, plot, places or time incidents. Although, it is not clear how gender and children's previous engagement in scent issues influence their language communication while representing a smelly story, it is true that they prefer smelly story- books rather than non-smelly as they told us (56 from the 60 persons), and they are more involved in stories that denote or express scents in storytelling or writing for children (54 persons).

\section{Suggestions-Discussion}

Smell essence is a typical leading publisher of "scented" books for children that are fun, engaging and encourage children to read. This new and exciting technology involves children in the story, as we noticed and allows them to interact with the books on a multisensory level. Children love books that make them laugh and yet will subtly take them on a journey.

The Fabulous Scented Books range, using certain patented technology to engage and educate children is another suggestion of working literacy through the senses in class. Some funny stories with a character named Theo, the little dog which loses his family is a book example as a global teaching tool. The book "helps" the dog finds his sense of smelling so as to find the family and pictures help in this procedure as an activity book for children. Hyde wrote a series of six books, beginning with Mo Smells Red. Her latest is Mo Smells Pink, in which the dog, Mo, smells pink grapefruit bubble bath and pink peppermint ice cream, among other pink things. She tried to use scents that would be safe and hypoallergenic for children, and she settled on essential oils. The oils are dispersed in a "Press 2 Smell" technology developed by Hyde that holds the scent until pressed. Each scent can be pressed up to 150,000 times. This example showed us that in a different culture these attempts can be used adapted to the cultural influences of the teaching strategies and environment.

In addition, to the general children's market, our study agrees with the suggestion that the books have had a great reception from learning disabled and autistic children. Research has shown that they react very positively to multi-sensory experiences and are able to learn better when more senses are used $^{1}$.

Although there are no smelly books in all languages and cultures, teachers can create as teaching tools hand- made storybooks with culturally and geographically common smells or select their alphabet of which smell reminds us each letter of the alphabet.

The area which we introduce and encourage is rather a new in educational experimentation in Greek Schools and the educational tools which help children summarize or recall a story from the smell that reminds a plot or certain episodes of a sequence in a storyline. We assume that there are probably as many alphabets of odors as the cultures and each one of us can affect in creating such a production. Publishing for authors and teaching for educators their own Scratch and Sniff Smelly Book is a step away of searching what the works in children's memory when other strategies of remembering certain details of a cognitive procedure collapses as a methodology. We suppose

\footnotetext{
${ }^{1}$ See also: //scentmarketingdigest.com/2011/07/13/author-debuts-scented-childrens-books/smells
} 
that our world would probably be a poor world, if there were not teaching activities without a possibility of a smelling world.

Educators and language researchers can think of all the wonderful "smells" associated with preparing, cooking and eating food. Children as students or just as explorers of language, especially the younger writers, can add scented ink to the books if they teachers are aware and willing to try what really works in learning language in multisensory terms of memory and cognition. The more senses we use the more real the experience is, as the pedagogy-father Friedrich Froebel encouraged educators since 1800 for using children's play as a freedom to learn, (Liebschner 1992). Humans have four genes for vision, whereas there are 1,000 allocated to smell, which means we have the ability to play with this opportunity and differentiate more than 10,000 combinations of smells. This information adds ideas at the process of searching for teaching methodology and applications in class. Perhaps, a children's scratch and sniff book, cookbook, holiday book, gift book, textbook, promotional book, new product announcement, wedding books, travel book, or many other creative ideas can help educators search how memory works in learning from their experience with the children. Sniff products and book creations are often designed as the most powerful of the five human senses in marketing as a home hobby of reading books and in education as a teaching methodology of sensory language items ${ }^{2}$.

\section{REFERENCES}

Ackerl, K., Atzmueller, M. and Grammer, K. 2002. The Scent of Fear, Neuroendocrinol Letters. 23, 79-84.

Buck L., \& Axel, R., 1991. A novel multigene family may encode odorant receptors: a molecular basis for odor recognition. Cell 65:175-187

Brookes JC, Hartoutsiou F, Horsfield AP, Stoneham AM (2007) Could humans recognize odor by phonon assisted tunnelling? Phys Rev Lett 98:

doi:10.1103/PhysRevLett.98.038101 [PubMed]

Burr, C., 2003. The Emperor of Scent: A Story of Perfume, Obsession, and the Last Mystery of the Senses. New York, NY, USA: Random House.

Burenhult, N. \&Majid A., 2013. Odors are expressible in language, as long as you speak the right language. Cognition, Volume 130, Issue 2, February 2014, Pages 266-270.

Classen, C., Howes, D., Synnott, A. 1994. Aroma: The cultural history of smell, UK: Routledge.

Crawford, D. C, Sounder, E., 1995. Smell disorders = danger. RN,58 (11), 4044.

Datta, S.R., et al., 2011. Detection and avoidance of a carnivore odor by prey. Proc. Natl. Acad. Sci. U.S.A. 108,11235-11240.doi:10.1073/pnas.1103317108. Doty, R.L., Laing, D.G., 2003. Psychophysical measurement of olfactory function, including odorant mixture assessment. In: Doty RL, ed. Handbook of Olfaction and Gustation. 2nd ed. New York: Marcel Dekker; 2003:203-228. Fendt, M., Kiyokawa Y. and Th. Endres, 2016. Scents that Matter-from Olfactory Stimulito Genes, Behaviors and Beyond. Front. Neuroscience, 09 February 2016| https://doi.org/10.3389/fnins.2016.00029

Ferrero, D.M., Lemon, J.K.,Fluegge,D.,Pashkovski,S.L., Korzan, W.J.,2011. Detection and avoidance of a carnivore odor by prey. Proceedings of the

\footnotetext{
${ }^{2}$ http://www.theguardian.com/books/booksblog/2012/mar/20/autumn-publishing-scented-books
} 
National Academy of Sciences of the United States of America: PNAS, vol. 108 no. 27 > David M. Ferrero, 11235-11240, doi: 10.1073/pnas. 1103317108 Edited* by David E. Clapham, Children's Hospital Boston, Howard Hughes Medical Institute, Boston, PNAS.

Firestein, S. ,2001. How the olfactory system makes sense of scents. Nature, 413:211-218.

Gillyatt, P., 1997. Loss of smell: when the nose doesn't know. Harvard Health Letter, 22, 6-8.

Gilbert, A, 2008, What the Nose Knows, Crown Publishers.

Kaiser, R. , 2006, Meaningful scents around the world. Wiley, VCH .

Keller, A., Vosshall L.B., 2004. A psychophysical test of the vibration theory of olfaction. Nat Neurosci, 7: 337-338 [PubMed]

Keller, A., Zhuang, H, Chi Q, Vosshall, L.B., Matsunami H., 2007. Genetic variation in a human odorant receptor alters odour perception. Nature 449:468-472.

Kratskin, I.L.,\& Belluzzi O., 2003. Anatomy and neurochemistry of the olfactory bulb. In: Doty RL, ed. Handbook of Olfaction and Gustation. 2nd ed. New York: Marcel Dekker; 2003: 139-164.

Kunio Kondoh, Zhonghua Lu, Xiaolan Ye, David P. Olson, Bradford B. Lowell\& Linda B. Buck, 2016. A specific area of olfactory cortex involved in stress hormone responses to predator odours. Nature. 532, 103-106 (07 April 2016) doi:10.1038/nature17156. Published online 21 March 2016.

Le Doux, J., 2012.Rethinking the emotional brain. Neuron 73,653-676.doi: $10.1016 /$ j.neuron.2012.02.004.

Liebschner, J. 1992. A Childs Work: Freedom and Guidance in Froebel's Educational Theory and Practice. Cambridge, U.K., The Lutterworth Press. Menashe I, Man O, Lancet D, Gilad, Y.,2003. Different noses for different people. Nat Genet 34:143-144.

Roberts, A. \& Williams J.M., 1992. The effect of olfactory stimulation on fluency, vividness of imagery and associated mood: a preliminary study., $\mathrm{Br} \mathrm{J}$ Med Psychol. 1992 Jun;65 (Pt 2):197-9.

Schilling, B., Kaiser, R., Natsch A. \&M. Gautschi, 2010. Investigation of odors in the fragrance industry Chemoecology, June 2010, Volume 20, Issue 2, pp 135-147, Springer.

Smith, C. G., 1992. Age incident of atrophy of olfactory nerves in man. J. Comp Neurol. 1992;77:589-594.

Spence, C.,2007. Audiovisual multisensory integration. Acoustical science and technology, 28(2), 61-70.

Wnuka E. \& Majida, A., 2014. Contact and isolation in hunter-gatherer language dynamics. Studies in Language,2014, Vol. 38 Issue 4, p956-981. 26p. 1 Diagram, 3 Charts, 1 Map.

\section{E-references}

http:/ /www.theguardian.com/books/booksblog/2012/mar/20/autumnpublishing-scented-books) http://smellessence.wordpress.com http:// scentmarketingdigest.com/2011/07/13/author-debuts-scentedchildrens-books/smells 